\title{
UN IMPORT ROMAN DIN ZONA ŞIMLEU SILVANIEI (JUD. SĂLAJ)
}

\author{
Horea Pop, Cristinel Plantos
}

\begin{abstract}
An imported Roman artifact at Şimleu Silvaniei (Sălaj county)
As the result of the most recent field research conducted in the area of the fortified acropolis at "Cetate" ("Dealul Cetății") at Şimleu Silvaniei (Sălaj district), there has been discovered a handle of a Roman bronze pot. Most probably the object has been discovered after the corrosion of the Terrace 1, an objective situated below the Dacian circumvallation from the upper part of the hill. The respective Terrace presented an important degree of occupation, consisting of no less than seven levels of occupation, and has been dismantled as a consequence of the construction of the circumvallation.
\end{abstract}

Cuvinte cheie: zona Şimleu Silvaniei, vas de bronz, import.

Key words: Şimleu Silvaniei area, bronze ware, import.

În urma unor cercetări de suprafață, de dată recentă, în zona acropolei fortificate din punctul "Cetate" ("Dealul Cetăţii”) de la Şimleu Silvaniei (jud. Sălaj) ${ }^{1}$, a fost găsită toarta unui vas roman de bronz. Cel mai probabil, obiectul a apărut ca urmare a erodării "Terasei 1", obiectiv aflat sub circumvalația dacică din zona superioară a dealului. Terasa în cauză, cu un nivel de locuire consistent, având nu mai puțin de şapte faze de amenajare ${ }^{2}$, a fost desființată în urma amenajării circumvalației mai sus amintite (pl. I/1-2).

\section{Descrierea piesei şi dimensiuni}

Toarta vasului este turnată din bronz, cu partea orizontală având aspectul unei păsări cu aripile desfăcute. Jumătatea superioară este modelată în forma unui cap şi gât de lebădă, în timp ce partea inferioară se încheie cu o protomă ce ilustrează un bust masculin cu barbă. (pl.2/1)

Dimensiunile piesei sunt: h. totală $-7,15 \mathrm{~cm}$; deschiderea brațelor $-4,8 \mathrm{~cm}$. Dimensiuni protomă: h. $-1,6 \mathrm{~cm} ; 1 .-1 \mathrm{~cm}$.

\section{Încadrare culturală, tipologică şi cronologică. Dispersie spațială}

Astfel de mânere provin de la căni bitronconice din bronz, cu fundul carenat, produse în ateliere romane din zona italică.

Tipologic, cănile de acest fel au fost împărţite în două tipuri, anume "Piatra Neamț", respectiv "Gallarte" (pl. II/2). În primul caz, caracteristică este toarta ce are la bază o aplică ilustrând un bust masculin cu barbă, în vreme ce în cazul tipului "Gallarte" definitorie este toarta având baza cordiformă cu spin şi cârlige ${ }^{4}$. Prin caracteristicile deja enunțate, exemplarul găsit la Şimleu Silvaniei se încadrează în primul tip discutat, anume "Piatra Neamț".

Spațiul pe care s-au răspândit astfel de obiecte în Europa este unul semnificativ, pornind din Italia ${ }^{5}$, ca zonă de geneză, spre un areal ce are ca limită vestică Spania ${ }^{6}$, iar spre est

\footnotetext{
${ }^{1}$ O descriere sintetică a sitului de la Şimleul Silvaniei “Cetate" la Pop 2006, 35-39; Pop et al. 2006, 84-86.

${ }^{2}$ Pop et al 2006, 84.

${ }^{3}$ Boube 1991, 23-25, fig. 1-2.

${ }^{4}$ Boube 1991, 23 .

${ }^{5}$ Graue 1974, pl. 33/10; Boube 1991, 27.
} 
arealul dintre Marea Neagră şi Marea Caspică․ În afara Europei, astfel de produse sunt documentate în nordul Africii ${ }^{8}$.

Din punct de vedere al tehnologiei de fabricație, astfel de căni au fost produse prin martelare, în ateliere din teritoriul etrusc, încă din prima parte a secolului al II-lea a.Chr. Ulterior, ele vor fi fabricate atât în ateliere campaniene, cât şi în cele nord-italice, nefiind exclusă şi varianta imitării lor în ateliere din alte spații ${ }^{9}$.

Din punct de vedere cronologic, cănile de tip "Piatra Neamț" îşi fac apariția ceva mai târziu decât cele de tip "Gallarte", cele mai timpurii contexte aparţinând ultimelor două decenii ale secolului al II-lea a.Chr., în timp ce limita târzie a uzitării lor coboară până la mijlocul secolului I a.Chr. ${ }^{10}$.

Pentru Dacia preromană, a fost sesizat faptul că aici, deşi s-au descoperit mai multe exemplare sau componente ale unor căni bitronconice din bronz ${ }^{11}$, doar în două cazuri a putut fi determinat tipul, anume la Piatra Neamț - "Bâtca Doamnei" (piesă ce a dat şi numele seriei), respectiv la Lupu (com. Cergău, jud. Alba), obiect încadrabil în tipul "Gallarte"12, la care se adaugă acum şi piesa de la Şimleu Silvaniei, încadrabilă în tipul "Piatra Neamț". Exemplarele din Dacia preromană se datează, în baza contextelor avute la dispoziție, cu precădere în prima jumătate a veacului I a. Chr. ${ }^{13}$.

\section{Concluzii}

În ciuda faptului că piesa discutată nu a apărut ca rezultat al unor cercetări arheologice (şi prin urmare nu dispunem de un context care să permită nuanțări), ea atestă, dacă mai era cazul, existența şi în această zonă a unor relații de schimb de mare distanță, rezultat al gusturilor cosmopolite ale aristocrației locale.

\section{BIBLIOGRAFIE}

Beldiman 1988 - C. Beldiman, $\mathrm{Cu}$ privire la difuziunea produselor din bronz italice în Dacia preromană (descoperirea de la Țigăneşti, jud. Teleorman), TD 9, 75-82.

Boube 1991 - C. Boube, Les cruches, La vaisselle tardo-républicaine en bronze. Actes de la tableronde CNRS organisé à Lattes du 26 au 28 avril 1990 par 1'UPR 290 (Lattes) et le GDR 125 (Dijon) (eds. M. Feugère, C. Rolley), Dijon, 23-45.

Graue 1974 - J. Graue, Die Gräberfelder von Ornavasso. Eine Studie zur Chronologie der Späten Latène - und frühen Kaiserzeit, Hamburg.

Pop et al. 2006 - H. Pop, I. Bejinariu, S. Băcueț-Crişan, D. Băcuieț-Crişan, D. Sana, Z. Csók, Şimleu Silvaniei. Monografie arheologică (I). Istoricul cercetărilor, Cluj-Napoca.

Pozo Rodriguez 200 - S. F. Pozo Rodriguez, La Vajilla Metálica - Bronce y Plata - Tardorepublicana en la Provincia Baetica, KJ 33, 417-434.

Rustoiu 2005 - A. Rustoiu, Dacia şi Italia în sec. I a.Chr. Comerțul cu vase de bronz în perioadă republican târzie. (Studiu preliminar), Comerț şi civilizație. Transilvania în contextual schimburilor comerciale şi cultural în antichitate - Trade and civilization. Transylvania in the frame of trade and cultural exchanges in Antiquity (eds. C. Cosma, A. Rustoiu), Cluj Napoca, 53-117.

Sedlmayer 1999 - H. Sedlmayer, Die römischen Bronzegefäße in Noricum, Montagnac.

\footnotetext{
${ }^{6}$ Boube 1991, 30; Pozo Rodriguez 2000, 419-420.

${ }^{7}$ Boube 1991, 30; Rustoiu 2005, 61.

${ }^{8}$ Boube 1991, 30; Rustoiu 2005, 61.

${ }^{9}$ Boube 1991, 27; Sedlmayer 1999, 11, pl. 1/4.

${ }^{10}$ Graue 1974, 237, pl.33/10; Boube 1991, 26.

${ }^{11}$ O primă sinteză ce le-a tratat în mod special la Beldiman 1988, 75-82.

${ }^{12}$ Rustoiu 2005, 61

${ }^{13}$ Întreaga discuție şi argumentație la Rustoiu 2005, 62.
} 


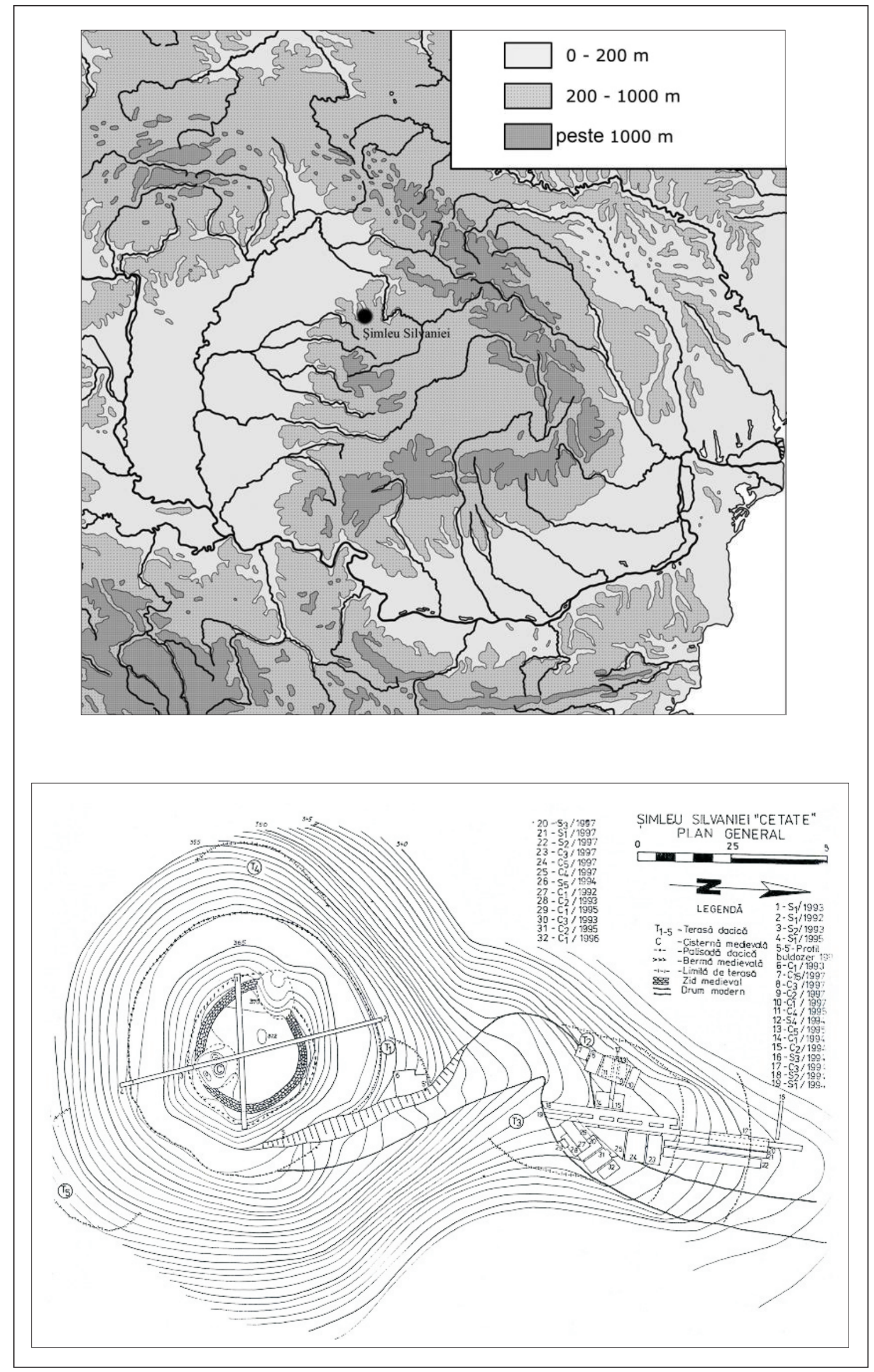

Pl. 1 


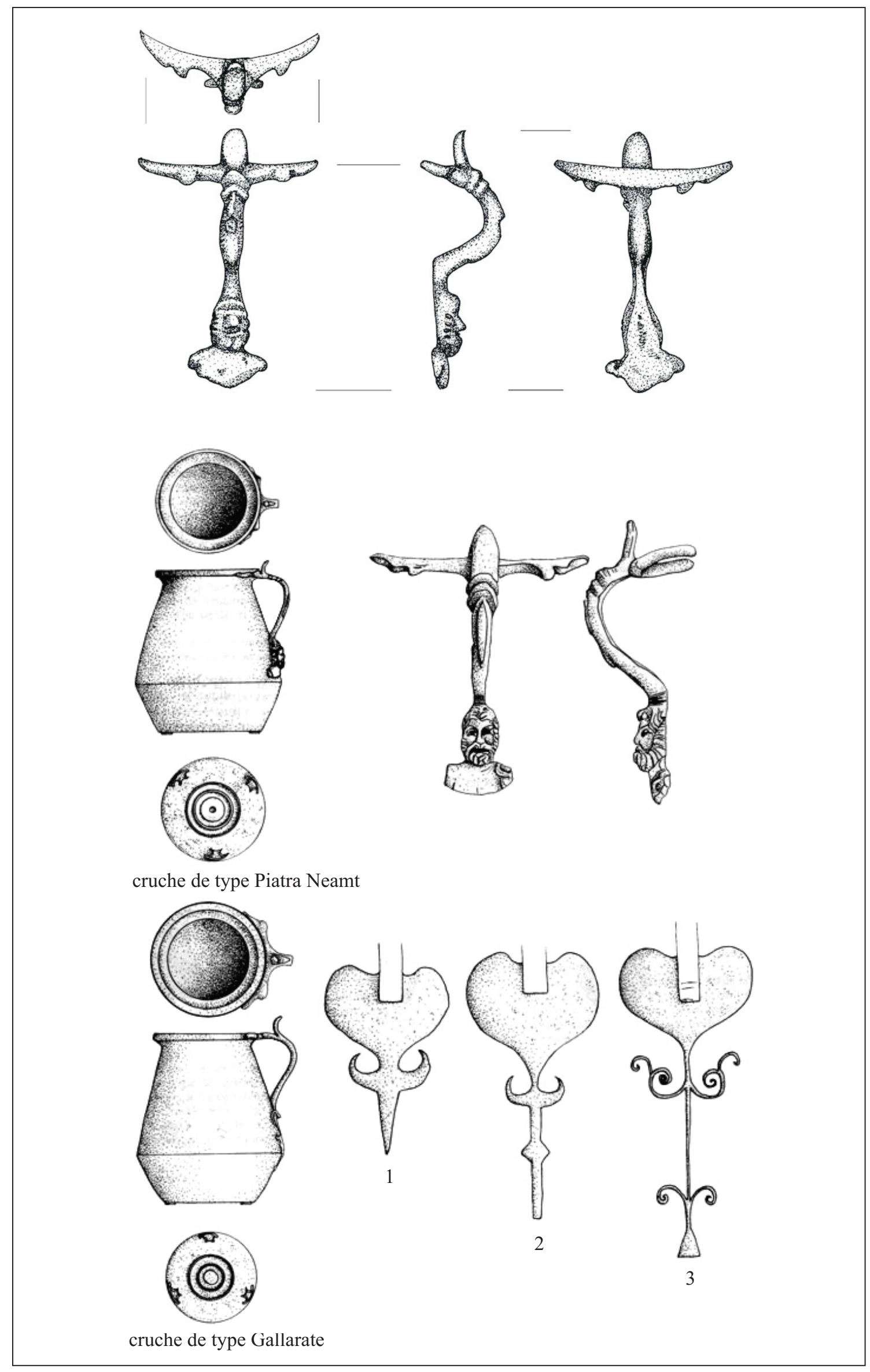

PI. 2 